\title{
Isolation and identification new bacterial strains isolated from different sources of Al-Rafidiyah oil field in Iraq
}

\author{
Asaad Faraj Hamzah ${ }^{*}$, Wijdan Hussein Al-Tamimi ${ }^{2}$, Saad Shakir Mahdi ${ }^{2}$ and Najla'a.Z.Alameri ${ }^{3}$ \\ ${ }^{1}$ Technical institute of Basrah, Southern Technical University, Basrah, Iraq. \\ ${ }^{2}$ Department of Biology, Science Collage, University of Basrah, Basrah, Iraq. \\ ${ }^{3}$ Researches and Quality Control Department, Basrah Oil Company, Iraq.
}

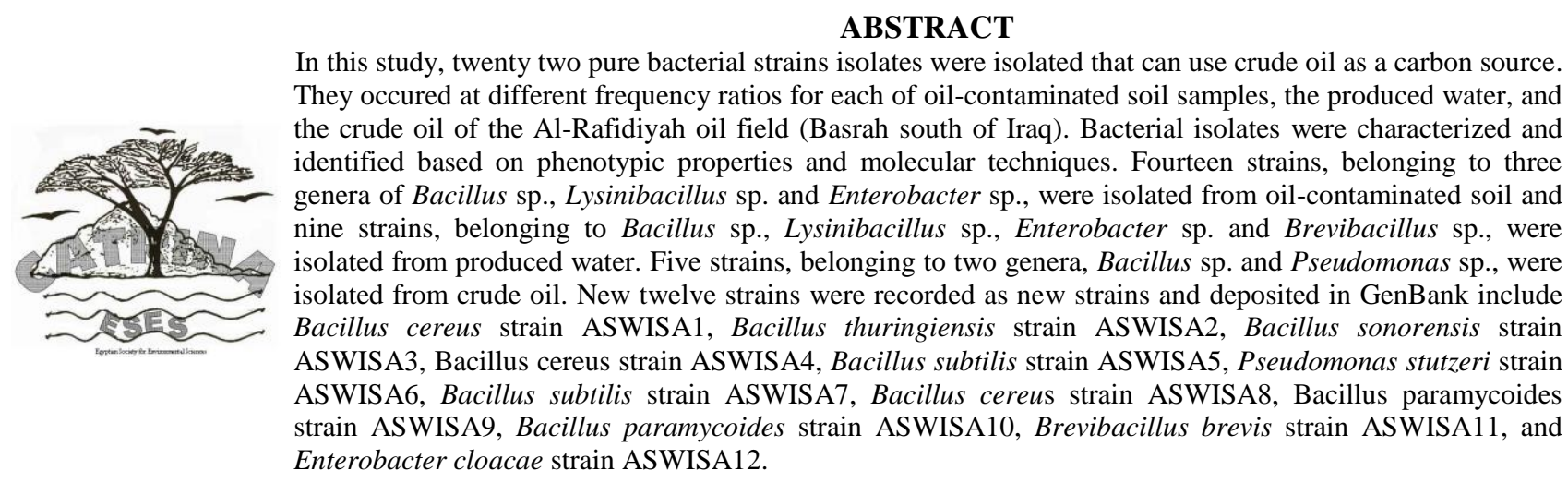

Keywords: Oil filed bacteria, petroleum microbiology, Crude oil bacteria.

\section{INTRODUCTION}

Due to the high temperature, anaerobic conditions, high pressures, degree of salinity and different $\mathrm{pH}$ in the oil reservoirs, it has become as a new extreme environment for the growth of living organisms in these reservoirs (Elshafie et al., 2013; Cai et al., 2015). Although the extreme conditions support life, numerous studies over the past few years proved microbes are found in several oil reservoir environments. Divers groups of microbes detected in oil reservoirs. Microbial studies of such harsh environment have shown the presence of good different metabolic activities such as sulphate reducers, various hyperthermophilic fermentative microorganism, acetogens and methanogens from oil reservoirs worldwide (Magot et al., 2000; Orphan et al., 2003). By molecular techniques a wide diversity of bacteria depending in abiotic factors such as oxygen, temperature, $\mathrm{pH}$, have been isolated from or have been detected in oil field samples (Telang et al., 1998; Al- Al-Tamimi 2015 Pannekens et al., 2019).

Oil reservoirs accommodate completely different phases wherever microorganisms will thrive, like formation water, and organic materials and crude oil (Kobayashi et al., 2012; Pannekens et al., 2019). Aerobic microorganisms have been found in oil reservoir with $\mathrm{pH}$ range $(6.0$ - 8.4) and temperatures ranging from $\left(20\right.$ to $\left.70^{\circ} \mathrm{C}\right)$. Some of these identified aerobic bacteria Kocuria rosea, Rhodococcus ruber, Gordonia rubropertincta, Arthrobacter oxydans, Bacillus subtilis, B. cereus Cellulomonas cellulans, Pseudomonas fluorescens and commonly bacteria of the genera Clostridium, Bacteroides, Thermoanaerobacter,Thermotogales, Petrotoga, Thermotoga, Geosporobacter, Desulfotomaculum, Caminicella represent anaerobic microflora were found in oil reservoirs
(Pannekens et al.,2019).The current study aimed to isolate and identify some the bacterial strains from a variety of sources in the Al-Rafidia oil field.

\section{MATERIALS AND METHOD}

The bacterial strains were isolated from Al-Rafidiya oil field, Basra south of Iraq, $30.16^{\circ} \mathrm{N} 47.42^{\circ} \mathrm{E}$. Twenty two samples of each oil contaminated soil, produced water and crude oil. The soil samples from the different sites of oil filed were collected in a sterile polythene bags at depth of 2-3 inches from the ground level using clean spatula, produced water samples were collected from separated tanks of water production. Meanwhile, the crude oil samples were collected from well head using 2.5 liter sterilized glass containers. All samples stored at $4^{\circ} \mathrm{C}$ in ice bag till transported to the laboratory. The daily reports of the oil field laboratories were used to for the physical and chemical properties of the samples, except the $\mathrm{pH}$ of soil which was measured in a 1:2 mixture of soil: water $(0.01 \mathrm{M}$ $\mathrm{CaCl}_{2}$ solution) using $\mathrm{pH}$ electrode (Burghal, 2015).

\section{Stimulation of indigenous microorganisms}

To stimulate the indigenous microorganisms, soil samples were crushed and sieved through $2 \mathrm{~mm}$ pore size (Fardoux et al., 2000 ; Dilmi et al ., 2017 ), then 5 $\mathrm{ml}$ soil suspension ( $5 \mathrm{~g}$ soil in $100 \mathrm{ml}), 5 \mathrm{ml}$ of produced water, and $5 \mathrm{ml}$ of crude oil were add separately to $250 \mathrm{ml}$ of Erlenmeyer flask contained 95 $\mathrm{ml}$ of mineral salt medium (MSM) composed of $2 \%$ of crude oil as a carbon source, $1 \mathrm{~g} / 1 \mathrm{KH}_{2} \mathrm{PO}_{4}, 6 \mathrm{~g} / \mathrm{l}$ $\mathrm{NaNO}_{3}, 1 \mathrm{~g} / \mathrm{K} \mathrm{K}_{2} \mathrm{HPO}_{4}, 0.02 \mathrm{~g} / \mathrm{FeSO}_{4}, 0.5 \mathrm{~g} / \mathrm{l} \mathrm{MgSO}$, and $0.02 \mathrm{~g} / 1 \mathrm{Na}_{2} \mathrm{MoO}_{4}$ at a pH of 7.0-7.2 (Zhao et al.,2017). The mixture was then shaken at $180 \mathrm{rpm}$ at $35^{\circ} \mathrm{C}$ for 48 hours using shaker incubator. Volume of 1 $\mathrm{ml}$ of the suspension was diluted serially and plated in triplicate on nutrient agar. The plates were incubated at 
$37{ }^{\circ} \mathrm{C}$. The various colonies obtained were taken and recultured by streaking methods on nutrient agar and MacConkey agar to obtain pure isolates which were kept on nutrient agar slants.

\section{Identification of the pure isolates}

(a) Morphological characterization

Pure isolated colonies that have grown on the nutrient agar plates were examined and recorded as colony morphological characteristics include color, size, shape, elevation, and margin. Micromorphology of bacterial isolates and their ability to Gram stain were recorded for all isolates via Gram stain protocol (Cheesbrough ,1991). Spore staining of bacterial cells, for all isolates, was carried out according to the method of Leboffe and Pierce (2015) .

\section{(b) Molecular identification}

Genomic DNA extraction

Genomic DNA was extracted from culture by using a commercial kit protocol (Promega Genomic DNA Purification Kit, USA ).

\section{Detection of genomic DNA}

According to Lee (2012), 0.25g of agarose powder was dissolved in $25 \mathrm{ml}$ of TBE buffer (1X) mixed gently, heated to near-boiling point, but avoid boiling, and added a very small amount of ethidium bromide dye using the micropipette tip and poured into casting tray with the comb inserted to make the appropriate special wells to add the DNA and left aside until it was solidified. Then the combs and the seal were removed gently from the tray and put down the gel gently in the electrophoresis chamber soaked by diluted TBE. Then $2 \mu \mathrm{l}$ of bromophenol blue stain was mixed with $4 \mu \mathrm{l}$ of extracted DNA on parafilm paper and loaded in wells of agarose by micropipette and electrophoresed by ban electric current from a power supply adjusted at $120 \mathrm{~mA}$ $60 \mathrm{~V}$ and for $35 \mathrm{~min}$. UV light transmitter was used to recognize the migrated bands.

\section{PCR amplification of 16S-rRNA gene}

16S rRNA genes were amplified using polymerase chain reaction (PCR). Universal specific primers $(27 \mathrm{~F}$ AGAGTTTGATCMTGGCTCAG) and (1492RT ACGGYTACCTTGTTCGACTT) were used. For PCR, a mixture contained $5 \mu \mathrm{l}$ of DNA, $2 \mu \mathrm{l}$ of each primers solution, master mix $25 \mu \mathrm{l}$ and $16 \mu \mathrm{l}$ nuclease free water was applied. Amplification was carried out with thermal cycle machine after initial denaturation for 3 min at $95^{\circ} \mathrm{C}, 30$ cycles were performed, each cycle is consisting of $20 \mathrm{sec}$. at $95{ }^{\circ} \mathrm{C}, 20 \mathrm{sec}$. at $55^{\circ} \mathrm{C}$ and 30 min. at $72^{\circ} \mathrm{C}$. Cycling was completed by a final elongation step at $72^{\circ} \mathrm{C}$ for $5 \mathrm{~min}$. (AL-sheshtawy et al., 2015; Al-Tamimi, 2015).

\section{Analysis of the PCR products}

After the amplification process, the PCR reaction products, with expected size of about $1.5 \mathrm{~kb}$, electrophoresed with $100 \mathrm{bp}$ DNA ladder of nucleic acid markers at $65 \mathrm{~V}$ and $120 \mathrm{~mA}$ for $35 \mathrm{~min}$. Agarose gel of $1.5 \%(\mathrm{w} / \mathrm{v})$ was used in TBE buffer $1 \mathrm{x}$. The gels were stained with $0.5 \mathrm{mg} / \mathrm{ml}$ of ethidium bromide solution. The DNA was visualized using UV transillumintor (Watanabe et al., 2001) and the results were photographed and documented.

\section{Sequence of PCR products}

The approximately 1500 bp 16S rDNA of each isolates were purified and sequencing at Yang ling Tianrun aoke biotechnology company laboratories in China. The bacterial 16S rDNA obtained sequencing was then aligned with known 16S rDNA sequences Gen Bank using the Basic Local Alignment Search Tool (BLAST) at the National Centre for Biotechnology Information (NCBI).

\section{RESULTS AND DISCUSSION}

\section{Main properties of samples}

Data recorded for physical and chemical properties of produced water, crude oil used in this study were collected from the daily production reports of the oil field laboratories as listed in Table (1) and Table (2).

\section{Isolation of bacterial strains from different collected samples \\ The best dilution to obtain single colonies showed $10^{-6}$ for soil samples, $10^{-2}$ for water samples, and $10^{-1}$ for crude oil samples. Screening the bacterial isolates for production of biosurfactant, twenty two pure bacterial strains were selected for their ability for bio-}

Table (1): Properties of produced water sample taken from Al-Rafidiyah oil field.

\begin{tabular}{ccccc}
\hline \hline Density $\left(\mathrm{g} / \mathbf{c m}^{3}\right)$ & Surface tension & $\mathbf{p H}$ & Salinity $(\mathbf{p p m})$ & Temperature $^{\mathbf{}} \mathbf{C}$ \\
\hline $0.854-0.862$ & $55.8-69.55$ & $6.9-7.5$ & $18-26$ & $35-46$ \\
\hline \hline
\end{tabular}

Table 2: Properties of crude oil of Al-Rafidiyah oil field.

\begin{tabular}{ccccc}
\hline \hline Density $\left(\mathbf{g} / \mathbf{c m}^{3}\right)$ & Viscosity(cp) & API Gravity & $\begin{array}{c}\text { Salt Content } \\
(\mathbf{p p m})\end{array}$ & Water content \% \\
\hline $0.852-0.861$ & 5.8 & $29-31$ & $14-18$ & $6.5-7.3$ \\
\hline \hline
\end{tabular}


surfactant production. The source of these bacteria strains were: eleven strains isolated from oil contaminated soil, seven strains isolated from produced water and four from crude oil and. The presence and distribution of bacterial strains obtained from different sampling sites indicates the ability of these microorganisms to utilize hydrocarbons as an energy source in these environments.

\section{Identification and characterization of the pure bacterial isolates}

(a)Morphological characterization

The phenotypic characteristics of the growing the colonies on nutrient agar medium, for all strains, were characterized. Based on Gram-staining, the results showed that $90.33 \%$ of the isolates were Grampositive while $9.67 \%$ of them were Gram-negative.

\section{(b)Molecular identification \\ DNA extraction and $16 S$ rRNA amplification analysis}

The results of electrophoresis technique for genomic DNA extraction showed pure and clear isolated DNA for all isolates which proceed for $16 \mathrm{~S}$ rRNA sequencing. Additionally, all isolates tested for the specific amplification of 16S rRNA gene sequences using a set of universal primers, $27 \mathrm{~F}$ and 1492R, yielded a single amplification of $\sim 1500 \mathrm{bp}$ for the entire isolates Figure (1). Based on partially sequenced of the sixty one obtained isolates, five genera were recognized and identified (Table 3). These genera were Bacillus, Lysinibacillus, Enterobacter, Brevibacillus and Pseud-omonas. Bacillus species were the most dominant genera.

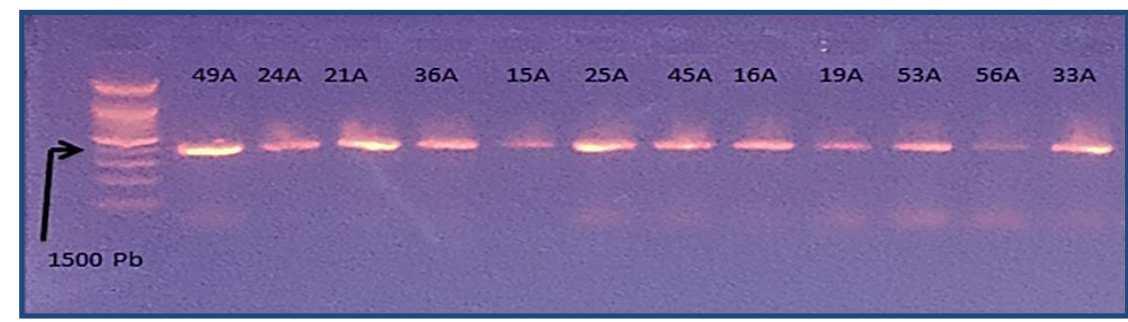

Figure (1): Agarose gel electrophoresis of 16S rRNA gene with 100 bp DNA ladder, showing . a single amplification band of $\sim 1500 \mathrm{bp}$ for selected isolates.

The frequency of each identified isolates revealed that the occurrence of the isolates obtained from contaminated soil were the highest and Bacillus subtilis IMG04 was the most frequented isolate (31\%.). Meanwhile, Bacillus cereus was reported four times out of twenty nine isolates recovered from oil contaminated-soil and three times out of 21 isolates recovered from produced water (Table 3 ). Although the recovered isolates from crude oil reported was less in count the genus Bacillus cereus was recorded in high frequency (27\% for both Bacillus cereus strain USO4 and Bacillus cereus strain M2). The second abundant genus was Bacillus subtilis strain followed by Bacillus paramycoides strain. Among identified genera, Pseudomonas stutzeristrain and Brevibacillus brevis strain were recoded once in crude oil and produced water, respectively.

According to the alignment and BLAST at NCBI the results of the new isolates 49A, 24A, 21A, 36A, 15A, 25A, 45A ,16A, 19A, 35A, 56A, and 33A are shown in Figure (2). These strains recorded a newt genetic identification depended on 16S rRNA and according to information available. After alignment with other $16 \mathrm{~S}$ rDNA sequences in GenBank, they showed a high degree of similarity (99-99.93\%) to reference strains.

The phylogenetic tree shown in Figure (2) reflects the relationships of the selected 22 different strains isolated from oil contaminated soil, produced water and crude oil samples. Among these 22 strains, 12 new strains were registered in the GenBank and were given the accession numbers as listed in Table (4).
Gram positive spore forming strains, belonging to the Bacillus genus, were the most dominant in the three sample sources. These results are in agreement with data reported by Al-Tamimi et al., (2019). In their study, they stated that Bacillus spp. was the most dominant bacterial species recovered from collected oil samples tested. In another study done by Hisham et al., (2019), they indicated the high diversity isolates obtained from petrol contaminated soil with the predominance of Bacillus sp.as biosurfactant producing in oil reservoir. Kumar et al., (2007) also, in their study, showed that Bacillus sp. isolated from oil contaminated soil produce biosurfactant over a wide range of $\mathrm{pH}$, salinity and temperature.

It is difficult or even impossible to find a suitable classification and generalization for Bacillus spp. bacteria because they possesses a great diversity of physiological characteristic that allowed these species to colonize almost all natural environments including soil, air, lake sediments, water and soil. Contaminated hydrocarbons-soil and fodder as well as harsh environments such as acidic thermal waters, salt marshes and hot springs and the sub-Antarctic soil, also reportend the abundance of Bacillus species (Claus and Berkeley, 1986; Gopal et al.,2015).

Evans et al., (2004), in their study, pointed that Bacillus spp. are often the predominant species in environments exposed to various petroleum hydrocarbons. They also found Bacillus licheniformis, B. firmus, B. subtilis, B. foraminis, B. from various soil samples and oil-contaminate soil. 
Table (3): Identified bacterial strains isolated from different studied sources, oil contaminated soil, produced water and crude oil, and their frequency.

\begin{tabular}{|c|c|c|c|}
\hline Source of isolation & Bacterial strain detected & $\begin{array}{c}\text { No.of } \\
\text { isolates }\end{array}$ & $\begin{array}{l}\text { Frequency } \\
(\%)\end{array}$ \\
\hline \multirow{15}{*}{$\begin{array}{l}\text { Oil contaminated } \\
\text { soil }\end{array}$} & Total Isolate No. 29 & & \\
\hline & Bacillus cereus strain USO4 & 4 & 13.79 \\
\hline & Bacillus cereus strain ASWISAl & 1 & 3.44 \\
\hline & Lysinibacillus boronitolerans strain SWIPB36 & 1 & 3.44 \\
\hline & Bacillus cereus strain A & 2 & 6.89 \\
\hline & Bacillus cereus strain ASWISA4 & 1 & 3.44 \\
\hline & Bacillus subtilis strain HDZK- BYSB7 & 1 & 3.44 \\
\hline & Bacillus thuringiensis strain LU3 & 3 & 10.3 \\
\hline & Bacillus subtilis IMG04 & 9 & 31 \\
\hline & Bacillus subtilis strain ASWISA5 & 1 & 3.44 \\
\hline & Bacillus paramycoides strain SKA22 & 2 & 6.89 \\
\hline & Bacillus paramycoides strain ASWISAIO & 1 & 3.44 \\
\hline & Enterobacter aerogenes strain B19 & 1 & 3.44 \\
\hline & Bacillus paramycoides strain ASWISA9 & 1 & 3.44 \\
\hline & $\begin{array}{l}\text { Bacillus licheniformis strain CC91 } \\
\text { Total Isolate No. } 21\end{array}$ & 2 & 6.89 \\
\hline \multirow{9}{*}{ Produced water } & Bacillus thuringiensis strain ASWISA2 & 1 & 4.76 \\
\hline & Lysinibacillus macroides strain ZCGT05 & 4 & 19.04 \\
\hline & Bacillus sonorensis strain ASWISA3 & 1 & 4.76 \\
\hline & Bacillus cereus strain ASWISA8 & 2 & 9.52 \\
\hline & Enterobacter cloacae strain & 3 & 14.28 \\
\hline & Brevibacillus brevis strain ASWISA11 & 1 & 4.76 \\
\hline & Enterobacter cloacae strain & 1 & 4.76 \\
\hline & Bacillus cereus strain EC3 $16 \mathrm{~S}$ & 4 & 19.04 \\
\hline & Bacillus cereus strain M2 & 4 & 19.04 \\
\hline \multirow{6}{*}{ Crude oil } & Total Isolate No. 11 & & \\
\hline & Bacillus cereus strain USO4 & 3 & 27 \\
\hline & Bacillus subtilis strain ASWISA7 & 1 & 0.9 \\
\hline & Pseudomonas stutzeri strain ASWISA6 & 1 & 0.9 \\
\hline & Bacillus cereus strain M2 & 3 & 27 \\
\hline & Bacillus thuringiensis strain LU3 & 3 & 27 \\
\hline
\end{tabular}

Morphological characterization of the selected twelve isolates (new record isolate) and their molecular identification showed their culture characteristic on nutrient agar and their ability for spore formation (Table 4). All isolates are rod shape and eight isolate out of twelve are spore former.

Identification based on molecular characterization was reported and revealed the presence of fourteen strains belonging to three genera of Bacillus sp., Lysinibacillus sp. and Enterobacter sp. were isolated from oil contaminated soil. Meanwhile, produced water showed recovery of nine strains belonging to Bacillus sp., Lysinibacillus sp., Enterobacter sp. and Brevibacillus sp., which reported only in this produced water sample (Table 4). Additional five strains belonging to two genera, Bacillus sp. and Pseudomonas sp., were isolated from crude oil.

The most common isolates recovered from the collected samples were belonging to Bacillus cereus and Bacillus subtilis and reported in a high frequency. Enterobacter aerogenes was recorded once in contaminated soil. Enterobacter cloacae was recorded twice in produced water sample. 


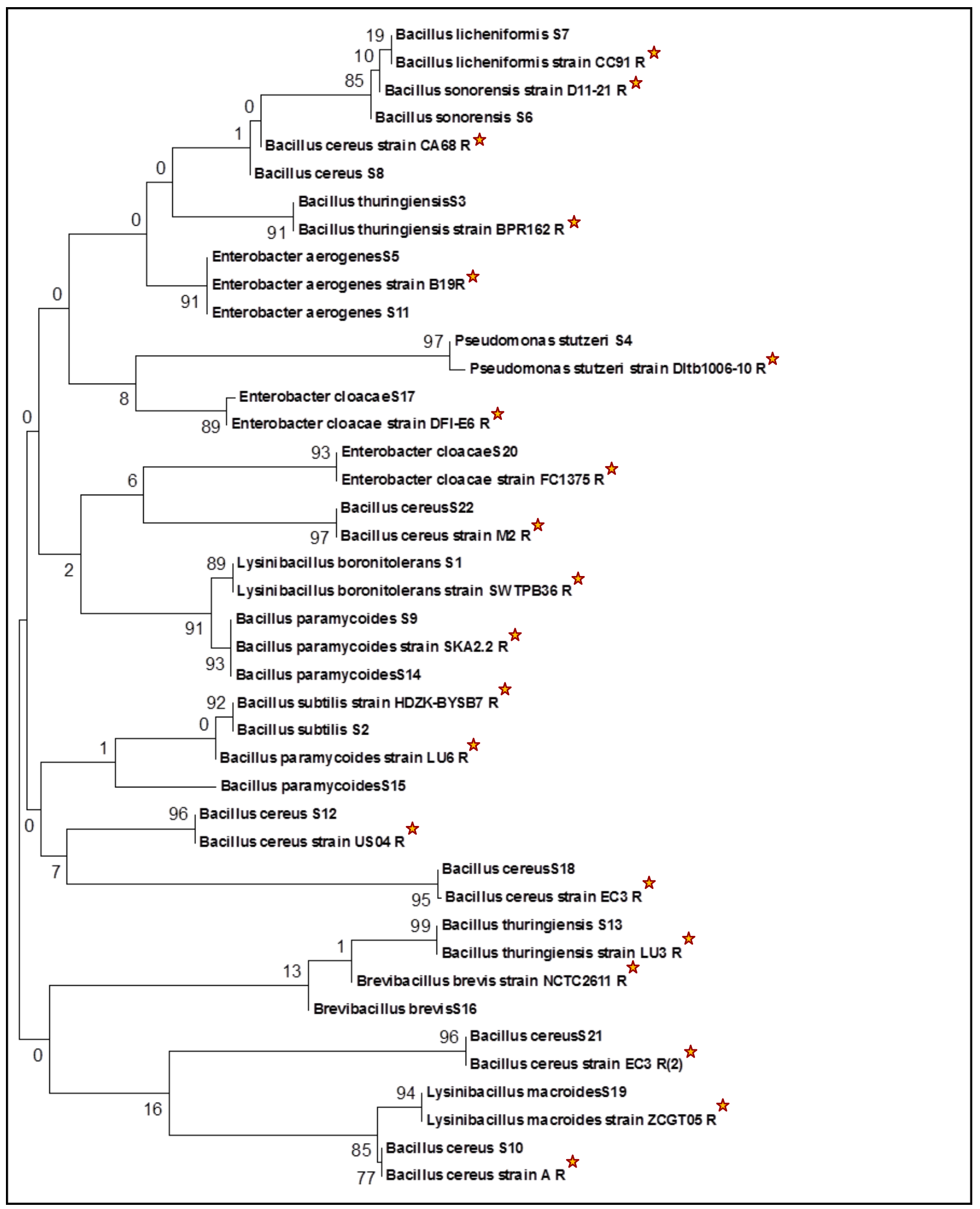

Figure (2): Rooted Neighbor Joining (N-J) phylogenetic tree constructed from concatenated sequences of 609 bp for each strain derived from an alignment of $16 \mathrm{~S}$ rDNA gene sequences then produced from analysis conducted in MEGA 6 program. This N-J tree showing the distribution and phylogenetic relationships between 22 different strains (yellow asterisk) isolated from oil contaminated soil, produced water and crude oil samples in this study and 21 reference strains $(\mathrm{R})$. All vertical branch lengths were drawn to scale Bootstrap values after 1000 repetitions are indicate. 
Table (4): Morphological characterization and BLAST results of the16SrRNA gene sequences of the isolates.

\begin{tabular}{|c|c|c|c|c|c|c|}
\hline Colony properties & $\begin{array}{c}\text { Gram } \\
\text { stain }\end{array}$ & $\begin{array}{c}\text { Cell } \\
\text { shape }\end{array}$ & Strain name & $\begin{array}{c}\text { Accession } \\
\text { number }\end{array}$ & $\begin{array}{l}\text { Percentage } \\
\text { identify }\end{array}$ & $\begin{array}{l}\text { Name of the new } \\
\text { strain in Gene Bank }\end{array}$ \\
\hline $\begin{array}{l}\text { Cream, raised, } \\
\text { circular and } \\
\text { undulate }\end{array}$ & + & $\begin{array}{l}\text { Rode } \\
\text { Spore } \\
\text { forming }\end{array}$ & $\begin{array}{l}\text { Bacillus } \\
\text { cereus strain } \\
\text { LDPE1 }\end{array}$ & MN309828 & $99 \%$ & $\begin{array}{l}\text { Bacillus cereus strain } \\
\text { ASWISA1 }\end{array}$ \\
\hline $\begin{array}{l}\text { Yellowish grey, } \\
\text {.Large, opaque, } \\
\text { flat }\end{array}$ & + & $\begin{array}{l}\text { Rode } \\
\text { Spore } \\
\text { forming }\end{array}$ & $\begin{array}{l}\text { Bacillus } \\
\text { thuringiensis } \\
\text { strain } \\
\text { BPR162 }\end{array}$ & MN309829 & $99 \%$ & $\begin{array}{l}\text { Bacillus thuringiensis } \\
\text { strain ASWISA2 }\end{array}$ \\
\hline $\begin{array}{l}\text { Brown yellowish, } \\
\text { large, irregular } \\
\text { undulate }\end{array}$ & + & $\begin{array}{l}\text { Rode } \\
\text { Spore } \\
\text { forming }\end{array}$ & $\begin{array}{l}\text { Bacillus } \\
\text { sonorensis } \\
\text { strain D11-21 }\end{array}$ & MN309830 & $99 \%$ & $\begin{array}{l}\text { Bacillus sonorensis } \\
\text { strain ASWISA3 }\end{array}$ \\
\hline $\begin{array}{l}\text { Yellowish grey, } \\
\text { Large, opaque, } \\
\text { granular, flat } \\
\text { colonies }\end{array}$ & + & $\begin{array}{l}\text { Rode } \\
\text { Spore } \\
\text { forming }\end{array}$ & $\begin{array}{l}\text { Bacillus } \\
\text { cereus strain } \\
\text { CA68 }\end{array}$ & MN309831 & $99 \%$ & $\begin{array}{l}\text { Bacillus cereus strain } \\
\text { ASWISA4 }\end{array}$ \\
\hline $\begin{array}{l}\text { white, large dull } \\
\text { irregular, large, } \\
\text { undulate, urbanite }\end{array}$ & + & $\begin{array}{l}\text { Rode } \\
\text { Spore } \\
\text { forming }\end{array}$ & $\begin{array}{l}\text { Bacillus } \\
\text { subtilis } \\
\text { IMG04 }\end{array}$ & MN309832 & $99 \%$ & $\begin{array}{l}\text { Bacillus subtilis strain } \\
\text { ASWISA5 }\end{array}$ \\
\hline $\begin{array}{l}\text { Yellowish grey, } \\
\text { round, large, } \\
\text { opaque, flat } \\
\text {.irregular }\end{array}$ & - & Short rode & $\begin{array}{l}\text { Pseudomonas } \\
\text { stutzeri strain } \\
\text { DItb1006-10 }\end{array}$ & MN309833 & $99 \%$ & $\begin{array}{l}\text { Pseudomonas stutzeri } \\
\text { strain ASWISA6 }\end{array}$ \\
\hline $\begin{array}{l}\text { Grey to yellow, } \\
\text { round, large, } \\
\text { opaque, flat } \\
\text {.irregular }\end{array}$ & - & Short rode & $\begin{array}{l}\text { Bacillus } \\
\text { subtilis } \\
\text { IMG04 }\end{array}$ & MN309834 & $99 \%$ & $\begin{array}{l}\text { Bacillus subtilis strain } \\
\text { ASWISA7 }\end{array}$ \\
\hline $\begin{array}{l}\text { Grey-yellow Large, } \\
\text { opaque, , flat }\end{array}$ & + & $\begin{array}{l}\text { Rode } \\
\text { Spore } \\
\text { forming }\end{array}$ & $\begin{array}{l}\text { Bacillus } \\
\text { cereus strain } \\
\text { ISU-02 }\end{array}$ & MN309835 & $99 \%$ & $\begin{array}{l}\text { Bacillus cereus strain } \\
\text { ASWISA8 }\end{array}$ \\
\hline $\begin{array}{l}\text { White, dull } \\
\text { irregular, large, } \\
\text { undulate, ,dry }\end{array}$ & + & $\begin{array}{l}\text { Rode } \\
\text { Spore } \\
\text { forming }\end{array}$ & $\begin{array}{l}\text { Bacillus } \\
\text { paramycoides } \\
\text { strain LU }\end{array}$ & MN309836 & $99 \%$ & $\begin{array}{l}\text { Bacillus paramycoides } \\
\text { strain ASWISA9 }\end{array}$ \\
\hline $\begin{array}{l}\text { White to cream, } \\
\text { circular, opaque, } \\
\text { waxy }\end{array}$ & + & $\begin{array}{l}\text { Rode } \\
\text { spore } \\
\text { forming }\end{array}$ & $\begin{array}{l}\text { Bacillus } \\
\text { paramycoides } \\
\text { strain } \\
\text { SKA2.2 }\end{array}$ & MN309837 & $99 \%$ & $\begin{array}{l}\text { Bacillus paramycoides } \\
\text { strain ASWISA10 }\end{array}$ \\
\hline $\begin{array}{l}\text { White, circular, } \\
\text { entire, smooth, flat, } \\
\text { translucent }\end{array}$ & + & $\begin{array}{l}\text { Rode } \\
\text { Spore } \\
\text { forming }\end{array}$ & $\begin{array}{l}\text { Brevibacillus } \\
\text { brevis strain } \\
\text { NCTC } 2611\end{array}$ & MN309838 & $98 \%$ & $\begin{array}{l}\text { Brevibacillus brevis } \\
\text { strain ASWISA11 }\end{array}$ \\
\hline $\begin{array}{l}\text { Cream, medium, } \\
\text { irregular, entire } \\
\text { margin }\end{array}$ & - & $\begin{array}{l}\text { Rod - non } \\
\text { spore } \\
\text { former }\end{array}$ & $\begin{array}{l}\text { Enterobacter } \\
\text { cloacae strain } \\
\text { DFI-E6 }\end{array}$ & MN309839 & $99 \%$ & $\begin{array}{l}\text { Enterobacter cloacae } \\
\text { strain ASWISA12 }\end{array}$ \\
\hline
\end{tabular}

\section{REFERENCES}

Al-Tamimi ,W.H. (2015). Using of Nitrate Reducing Bacteria Isolated From Produced Water of Oil Fields in Basra in Control of Biogenic Hydrogen Sulfide Produced by Sulfate Reducing Bacteria. $\mathrm{PhD}$. Thesis. University of Basrah.

Al-Tamimi ,W.H.., Lazim, S. A., AL-Sahib, M. A. A., Hameed, Z. M., AL-Amara, S. S. M., Burgal, A. A., \& AL-Maqtoofi, M. Y.(2019) Improved oil recovery by using biosurfactant produced from bacilli bacteria isolated from oil reservoir in Iraq. Poll Res., 38 (3), 551-556.

Burghal .A.A.(2015). Biodegradation and bioremediation of petroleum hydrocarbons by Streptomyces and Nocardiopsis strains isolated from oil contaminated soil of Basrah Governorate-Iraq. $\mathrm{PhD}$. Thesis. University of Basrah.

Cai, M., Nie, Y., Chi, C. Q., Tang, Y. Q., Li, Y., Wang, X. B., \& Wu, X. L. (2015). Crudeoil as a microbial seed bank with unexpected functional potentials. Scientific Reports, 5, 16057. 
Cheesbrough, M. (1991). Medical Laboratory Manual for Tropical Countries. University Press, Cambridge.

Claus, D., \& Berkeley, R. C. (1986). W. Genus Bacillus Cohn 1872, 174 AL. Bergey's Manual of Systematic Bacteriology. Baltimore, Md: Williams and Wilkins, 1105-1139.

Dilmi, F., Chibani, A., \& Rezkallah, K. S. (2017). Isolation and molecular identification of

hydrocarbon degrading bacteria from oilcontaminated soil. International Journal of Biosciences, 11(4), 272-283.

Elshafie, A. E., Al-Bahry, S., Al-Wahaibi, Y., AlBemani, A., Joshi, S., Al-Maini, R., ... \& AlMandhari, M. (2013). Bacterial diversity of Omani oil wells using culture dependent and independent techniques. APCBEE Procedia, 5, 247-252.

El-Sheshtawy, H. S., Aiad, I., Osman, M. E., AboELnasr, A. A., \& Kobisy, A. S. (2015). Production of biosurfactant from Bacillus licheniformis for microbial enhanced oil recovery and inhibition the growth of sulfate reducing bacteria. Egyptian Journal of Petroleum, 24(2), 155-162.

Evans, F. F., Rosado, A. S., Sebastián, G. V., Casella, R., Machado, P. L., Holmström, C., ... \& Seldin, L. (2004). Impact of oil contamination and biostimulation on the diversity of indigenous bacterial communities in soil microcosms. FEMS Microbiology Ecology, 49(2), 295-305.

Fardoux, J., Fernandes, P., Niane-Badiane, A., \& Chotte, J. L. (2000). Effete du séchage d'échantillons d'un sol ferrugineux tropical sur la détermination de la biomasse microbienne: comparaison de deux méthodes biocidales de référence. Etude et Gestion des sols, 7(4), 385- 394.

Gopal, N., Hill, C., Ross, P. R., Beresford, T. P., Fenelon, M. A., \& Cotter, P. D. (2015). The prevalence and control of Bacillus and related spore-forming bacteria in the dairy industry. Frontiers in Microbiology, 6, 1418.

Hisham, M. B., Hanisah, N., Ibrahim, M. F., Ramli, N., \& Abd-Aziz, S. (2019). Production of biosurfactant produced from used cooking oil by Bacillus sp. HIP3 for heavy metals removal. Molecules, 24(14), 2617.
Kumar, A. S., Mody, K., \& Jha, B. (2007). Evaluation of biosurfactant/bioemulsifier production by a marine bacterium. Bulletin of Environmental Contamination and Toxicology, 79(6), 617-621.

Leboffe, M. J., \& Pierce, B. E. (2015). Microbiology: Laboratory Theory and Application.Morton Publishing Company.

Lee, P. Y., Costumbrado, J., Hsu, C. Y., \& Kim, Y. H. (2012). Agarose gel electrophoresis for the separation of DNA fragments. JoVE (Journal of Visualized Experiments), (62), e3923.

Magot, M., Ollivier, B., \& Patel, B. K. (2000). Microbiology of petroleum reservoirs. Antonie van Leeuwenhoek, 77(2), 103-116.

Orphan, V. J., Taylor, L. T., Hafenbradl, D., \& Delong, E. F. (2000). Culture-dependent and cultureindependent characterization of microbial assemblages associated with high- temperature petroleum reservoirs. Appl. Environ. Microbiol., 66(2), 700-711.

Pannekens, M., Kroll, L., Müller, H., Mbow, F. T., \& Meckenstock, R. U. (2019). Oil reservoirs, an exceptional habitat for microorganisms. New Biotechnology, 49, 1-9.

Tabatabaee, A., Mazaheri Assadi, M., Noohi, A. and Sajadian, V., 2005. Isolation of biosurfactant producing bacteria from oil reservoirs. Iranian J. Env. Health Sci. Eng., 2(1): 6- 12.

Telang, A. J., Ebert, S., Foght, J. M., Westlake, D. W., \& Voordouw, G. (1998). Effects of two diamine biocides on the microbial community from an oil field. Canadian Journal of Microbiology, 44(11), 1060-1065.

Watnabe, K.; Kodama,Y. and Harayama, S. (2001). Design and evaluation of PCR primers to amplify bacterial 16S ribosomal DNA fragments used for community fingerprinting. J. Microbiol. Meth., 44: $253-262$.

Zhao, F., Shi, R., Cui, Q., Han, S., Dong, H., \& Zhang, Y. (2017). Biosurfactant production under diverse conditions by two kinds of biosurfactant-producing bacteria for microbial enhanced oil recovery. Journal of Petroleum Science and Engineering, 157, 124-130. 


\title{
عزل وتثخيص سالالت بكتيرية جديدة معزولة من مصادر مختلفة لحقل الرافضية النفطي في العراق
}

\author{
اسعد فرج حمزة'، وجدان حسين التميمي² سعد شاكر مهدي، نجلاء زكي العامري3

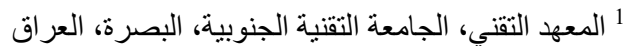 \\ 2 ${ }^{2}$

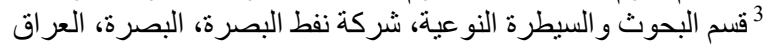

\author{
الملخص العربي
}

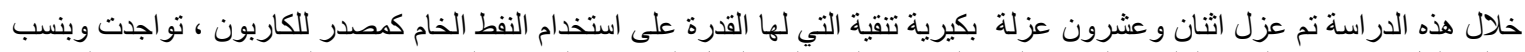

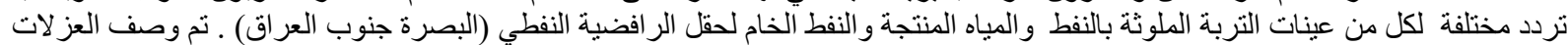

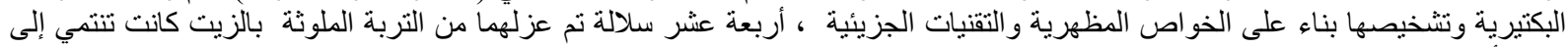

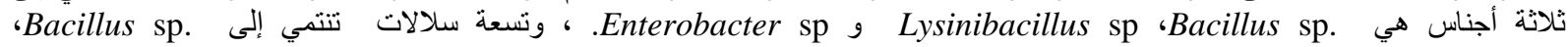

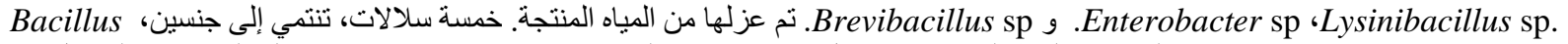

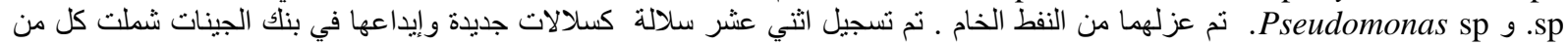
Bacillus sonorensis و Bacillus thuringiensis strain ASWISA2 و Bacillus cereus strain ASWISA1 السلالات Pseudomonas stutzeri gacillus subtilis strain ASWISA5 ‘Bacillus cereus strain ASWISA4 'strainASWISA3 Bacillus paramycoides 'Bacillus cereus strain ASWISA8 'Bacillus subtilis strain ASWISA7 'strain ASWISA6 (Brevibacillus brevis strain ASWISA11 Bacillus paramycoides strain ASWISA10 'strain ASWISA9 